\title{
EVALUATION OF TWO INFANTS WITH MYOTONIC DYSTROPHY BY THE MCFIE'S DIAGRAM FROM THE RESULTS OF WISC
}

\author{
CRISTINA MARIA DUARTE WIGG*, LUIZ ANTONIO ALVES DURO**
}

\begin{abstract}
In this paper the authors disclose the result of a research carried out on two brothers whose parents were first cousins, being the gene transmitted by the father. The psychological test Wechsler Intelligence Scale of Children (WISC) was used in two occasions in order to assess the verbal and non-verbal skills. FRM and IRM were nine and eleven-year-old respectively, in the first examination, being the former thirteen and the latter fifteen-year-old on the second one. A comparison between the McFie's diagram and the WISC scores was made: the McFie's diagram showed the impairment severity in each cortical lobe when the left hemisphere was compared with the right one. The McFie's diagram was made from WISC's scores: the McFie's diagram showed the impairment severity in each cortical lobe when the left hemisphere was compared with the right one. On the second examination the performance was worse than in the first, mainly in the non-verbal aspects. The IRM's diagram showed a reduction in the right frontal and parietal lobes. In the FRM's diagram a reduction in the left frontal, temporal and parietal lobes, and also, in the right parietal lobe was found. The visual-spatial constructive aspects showed greatest impairment in this result.
\end{abstract}

KEY WORDS: myotonic dystrophy, WISC, McFie's diagram.

\section{Avaliação de duas crianças com distrofia miotônica pelo diagrama de McFie a partir dos resultados do WISC}

RESUMO - Neste relato os autores apresentam o resultado de estudo realizado em dois irmãos com distrofia miotônica, cujos pais eram primos em primeiro grau, sendo o gene transmitido pelo pai. O teste psicológico Wechsler - Escala de Inteligência para Crianças (WISC) foi utilizado em duas ocasiões a fim de pesquisar as habilidades verbais e não-verbais. FRM e IRM contavam 9 e 11 anos de idade, respectivamente, no primeiro exame, no segundo exame as respectivas idades eram 13 e 15 anos. Uma análise através do diagrama de McFie a partir dos resultados do WISC foi realizada. O diagrama de McFie é construído a partir dos resultados do WISC. As avaliações dos diagramas dos pacientes denotaram a intensidade do acometimento em cada lobo cortical, tanto do lado esquerdo quanto do lado direito. Verificou-se que no segundo exame o desempenho foi pior que no primeiro, especialmente quanto aos aspectos não-verbais. O diagrama de IRM mostrou uma contração nos lobos frontal e parietal à direita. O de FRM apresentou redução no frontal, temporal e parietal à esquerda e também no parietal direito. Os aspectos visuo-espaciais construtivos foram os que apresentaram os maiores comprometimentos.

PALAVRAS-CHAVE: distrofia miotônica, WISC, diagrama de McFie, testes psicológicos.

The Steinert's disease, known as Myotonic dystrophy, is a genetic disorder caused by the gene that has been localized to the long arm of chromosome 19, just below the centromere. Several are the signs and symptoms produced by the disease such as baldness, muscular atrophy, cardiac and respiratory involvement. According to Dyken and Harper ${ }^{1}$, facial paralysis, feeble sucking and

*Professor in Department of Psychology at Instituto de Psicologia from Universidade Federal do Rio de Janeiro; **Professor of Neurology and Chief of the Myopathies Division at Instituto de Neurologia Deolindo Couto (INDC) of Universidade Federal do Rio de Janeiro. Aceite: 28-maio-1998.

Dr. Luiz Antonio Alves Duro - Setor de Miopatias - Instituto de Neurologia Deolindo Couto, Universidade Federal do Rio de Janeiro - Avenida Venceslau Brás 95 - 22290-140 Rio de Janeiro RJ - Brasil. 
swallowing, generalized hypotonia and talipes equinovalgus may be present at birth. Respiratory insufficiency is very common.

Evaluation of patients of different ages with myotonic dystrophy revealed that the visualspatial and constructional impairment, and also the social behavior, characterized by sudden changes of mood (depression/inhibition or agitation/aggressiveness) and the "know-to do" disturbance were very frequent. Visual-spatial and constructive disabilities concerning cognitive aspects have been our aim, as we have already reported ${ }^{2-4}$, when we described attention disturbance, spatial conception, abstraction and visual-motor perception.

Morphologic degeneration in the patients' brain was detailed by Culebras et al. ${ }^{5}$, suggesting that the thalamic impairment could be related to the great difficulty that patients have in constructing pictures from models. The greatest percentage of the disease in the neonatal form is transmitted by the mother. According to some authors such as Vanier ${ }^{6}$, all neonatal cases seem inherited from the mother. Through a longitudinal study of a child, Vanier ${ }^{6}$ verified progressive decline in the IQ. Calderon $^{7}$ observed severe retardation in 6 children. Also, in a longitudinal study Zellweger and Ionasescu ${ }^{8}$ described intellectual decline in 2 children.

On the bibliography revision no longitudinal study in myotonic dystrophy employing the McFie's diagram was found. This diagram provides the graphic visualization of cerebral lesions in the right and left hemispheres. The verbal and non-verbal cognitive areas are evaluated according to the weighted scores found in the Wechsler subtests ${ }^{9,10}$.

Due to the cognitive impairment found in the majority of myotonic dystrophy cases, especially in the performance area, we analyzed the results of two tests in which the Wechsler Intelligence Scale of Children (WISC) was administered. The possibility of comparing verbal and non-verbal performance with cerebral impairment caused us to use the McFie's diagram in order to enlarge our findings.

\section{METHODS}

FRM (male) and IRM (female) were brothers of 9 and 11 years, respectively, in the first test, being the first 13 and the latter 15 years on the second one. The time span between examinations was 4 years. Their parents were consanguineous (first cousins) (Table 1).

The following subtests of the WISC were employed: a) numbers (left frontal lobe); b) labyrinth, picture copletion and constructing objects (right frontal lobe); c) similarities (left temporal lobe); d) code and picture arrangement (right temporal lobe); e) arithmetic (left parietal lobe); f) cubes (right parietal lobe). The scores (without any deduction) obtained from the subtests performed by the two children were converted into weighted scores and then in IQ (Table 2, Figs 2 and 3). The weighted results were used in the McFie's diagram and localized in cerebral areas and distinct hemispheres (Figs 4 to 7). When one lobe was tested for more than one subtest, we applied the average of these subtests on the diagram.

The McFie's diagram is punctuated according to the weighted scores obtained from the WISC scores (without any deduction). The relation between cerebral functions and its localization are considered in the diagram and from this, the WISC subtests are adapted ${ }^{11,12}$.

The diagram is constructed of concentric circle, in a form of a target and the value of the smallest circle is 2 points, the next is 4 points, being successive in this way 2 by 2 points. This figure is divided in the middle and one side corresponds to the right hemisphere and the other to the left one. Two straight lines are drawn, crossing themselves in the medium line in a X form. So, we divide each side of the frontal, temporal and parietal lobes and the got points are localized in the middle of the lobe as well as in the correspondent point of the figure. For example, if the punctuation of the parietal lobe was 6 , the point will be signalized in the middle of the line which delimits the 3 rd circle.

Thus, on being punctuated, the diagram must allow the visualization of a profile in a circular field through the linkage of the weighted scores marked on itself. A graphic of the verbal and non-verbal performance of each case in the first and second analysis is included (Figure 1). 


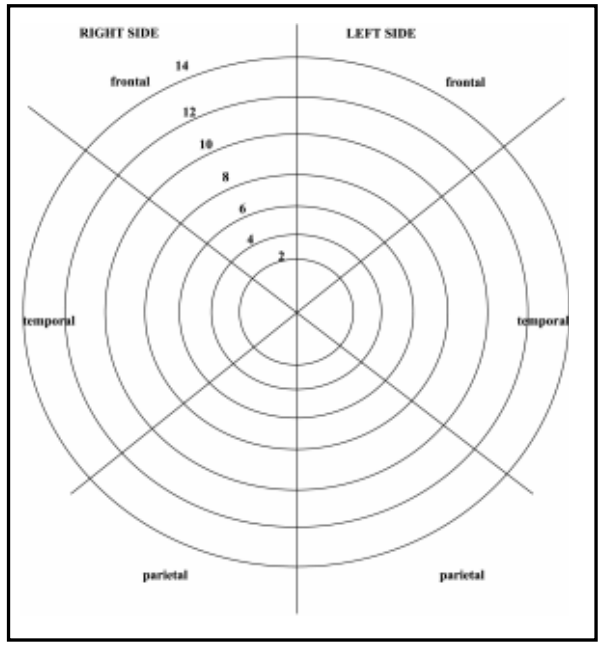

Fig 1. McFie's diagram model.

\section{RESULTS}

The results of the comparison between the first and second evaluation showed an improvement in IRM's verbal ability, whereas in performance function (non-verbal) there was a considerable decline. Only in the code subtest a level increase was verified. It was also observed that the improvement in the verbal area was more significative than in performance function (completion and arrangement of pictures and cubes). It is worth to say that IRM went on studying in this meantime, what might have helped her improving her performance. Besides this, it is remarkable the difference between verbal and non-verbal performance, characterizing great disability in the visual-spatial and constructive aspects (tables 1 and 2).

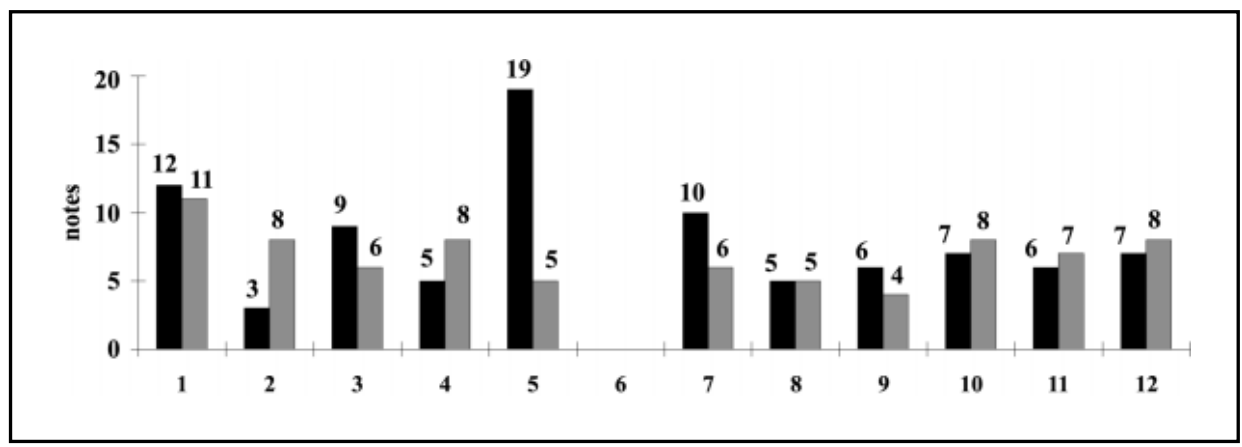

Fig 2. FRM's results. In each columns pair, the first refers to the first evaluation and the second to the second one. The columns pair from 1 to 5 correspond to the verbal tests and the ones from 7 to 12 to the nonverbal.

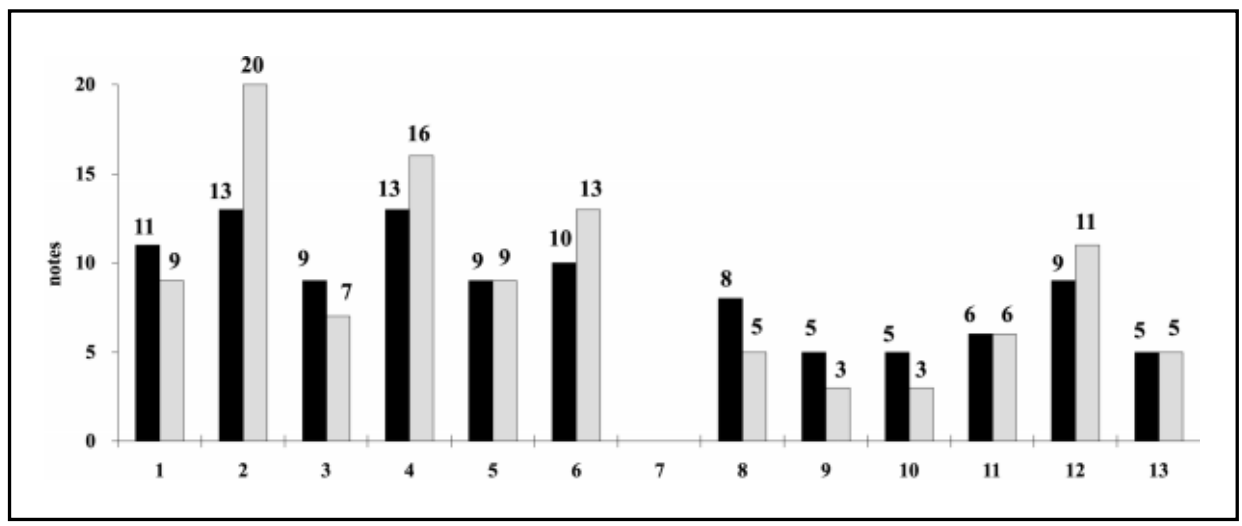

Fig 3. IRM's results. In each columns pair, the first refers to the first evaluation and the second to the second one. The columns pair from 1 to 6 correspond to the verbal tests and the ones from 8 to 13 to the nonverbal. 
Table 1. FRM and IRM subtests results.

\begin{tabular}{lcccccc}
\hline Subtests & \multicolumn{2}{c}{ FRM } & & \multicolumn{2}{c}{ IRM } \\
\cline { 2 - 3 } \cline { 6 - 7 } & 1st & 2nd & & 1st & 2nd \\
\hline information & 08 & 09 & & 11 & 09 \\
comprehension & 12 & 11 & & 13 & 20 \\
arithmetic & 03 & 08 & & 09 & 07 \\
similarities & 09 & 06 & & 13 & 16 \\
numbers & 05 & 08 & & 09 & 09 \\
vocabulary & 19 & 05 & & 10 & 13 \\
picture completion & 10 & 06 & & 08 & 05 \\
picture arrangement & 05 & 05 & & 05 & 03 \\
cubes & 06 & 04 & & 05 & 03 \\
constructing object & 07 & 08 & & 06 & 06 \\
code & 06 & 07 & & 09 & 11 \\
labyrinth & 07 & 08 & & 05 & 05 \\
\hline
\end{tabular}

Legend: 1st, first evaluation; 2nd, second evaluation.

Table 2. IQ results of patients.

\begin{tabular}{cccc}
\hline \multicolumn{5}{c}{ First evaluation } \\
\hline Patient FRM & \multicolumn{2}{c}{ Patient IRM } \\
\hline IQ & classification & IQ & classification \\
\hline 108 & average & 096 & average \\
087 & below average & 083 & below average \\
098 & average & 089 & average \\
\hline \multicolumn{5}{c}{ Second evaluation } \\
\hline \multicolumn{5}{c}{ Patient FRM } & Patient IRM \\
\hline IQ & classification & IQ & classification \\
\hline 119 & above average & 130 & above average \\
083 & below average & 076 & limitrophe \\
102 & average & 105 & average \\
\hline \multicolumn{5}{c}{}
\end{tabular}

In the McFie's diagram it is possible to visualize that the field related to the right hemisphere (frontal, temporal and parietal regions) appeared more limited than the left, specially on the second examination (Figs 4 to 7). This fact showed that verbal aspects once being stimulated may not impair as much as the non-verbal that, yet being stimulated, showed a decline.

On the second FRM's examination a decrease in verbal aspects was found, whereas memory and ability to do mental arithmetic had improved. As to the subtests of non-verbal ability, a decline in the performance of completion and figures arrangement and Koh's cubes was verified..

It is evident that in FRM's case there was a decrease of the field related to the left hemisphere (verbal similarities) and in both IRM and FRM's cases a decrease of the field related to the right 


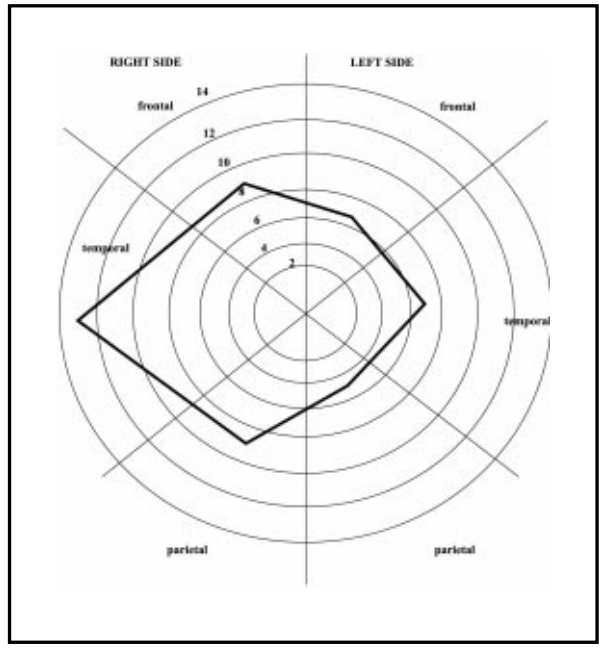

Fig 4. IRM's first evaluation by the McFie's diagram.

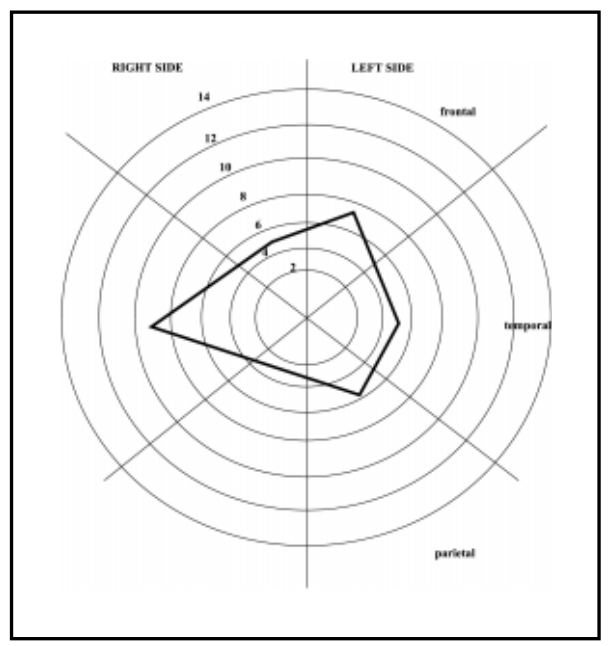

Fig 6. FRM's first evaluation by the McFie's diagram.

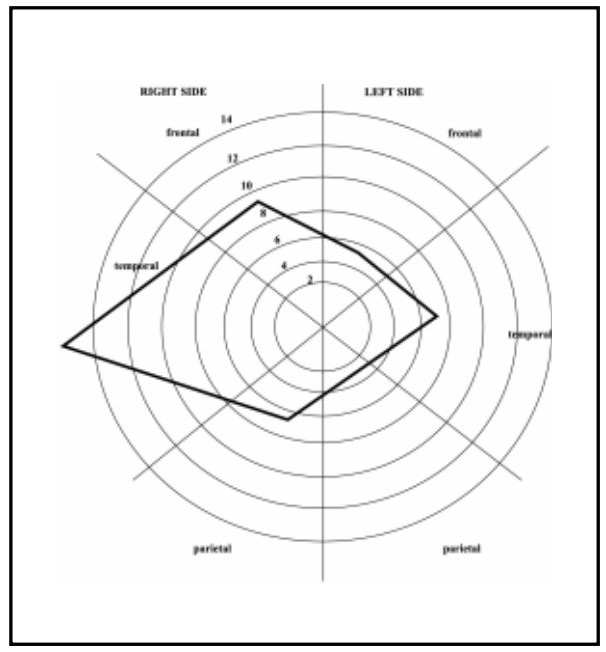

Fig 5. IRM's second evaluation by the McFie's diagram.

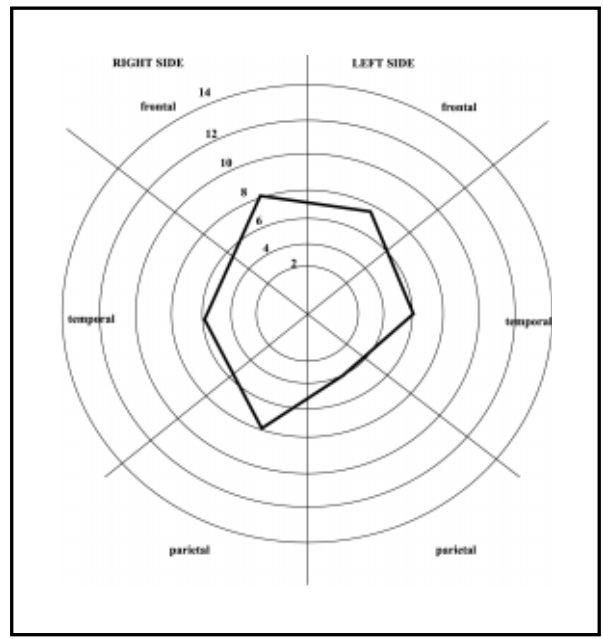

Fig 7. FRM's second evaluation by the McFie's diagram.

(figures arrangement and completion and Koh's cubes ) was present. The performance related to the cubes subtests was more impaired.

\section{DISCUSSION}

Hanafusa et al. ${ }^{13}$ pointed out that the latency abnormality of P300 component suggests that patients' cognitive functions and the information performance could be impaired due to the disorders of the brain development. According to Adams and Victor ${ }^{14}$, lesions in the non dominant parietal lobe determine among other alterations the visual-spatial agnosia disturbance. In bilateral lesions of the parietal lobes severe constructional apraxia may appear. Paterson and Zangwill ${ }^{15}$ reported the case of two patients with visual-spatial agnosia due to traumatism. The patients failed on tasks involving spatial analysis and showed disorganization of construction under visual control. This was clear in drawing and copying tests, and in figures construction. 
Lenz ${ }^{16}$ pointed out the systematic impairment of the visual-coordinations associated with parieto-occiptal injuries of the right hemisphere. In the 6 cases with degeneration in the right hemisphere there was a distortion in the coordination system. That was accentuated on freeze the scalp region below the affected bone. When patients with similar lesions in the dominant hemisphere were studied, such alterations were not found. It was concluded that the results pointed out the great importance of the cortical parieto-occiptal right area in the visual-spatial sensomotor orientation.

McFie et al. ${ }^{17}$ analyzed 8 cases of various visual-spatial alteration involving posterior portions of the right cerebral hemisphere in dextrous patients, especially the parieto-occiptal regions. These disabilities were defined by Lange (1936, apud McFie et al. ${ }^{17}$ ) under the term "apractognosia" for spatial conception and as "planotopokinesia" by Marie et al. ${ }^{18}$. Censori ${ }^{19}$ pointed out the importance of visual-spatial and constructive impairment, as Penez (1978, apud Granier $\left.{ }^{20}\right)$. and Walker et al. ${ }^{21}$ have also done.

It is important to notice that the right and left frontal areas in the two cases were impaired. The performance of both patients declined from first to the second evaluation. This impairment might be due to frontal and parietal lobes dysfunction, being the first responsible by behavior alterations and the latter by the non dominant side.

We observed that in the two cases, there was a decline of the performance due to the cerebral function capacity impairment, especially in the right hemisphere. The inherent functions of the left hemisphere were not so impaired. The most compromised functions (figures arrangement and completion and cubes) included the "know-to-do" ability and the visual-spatial constructive aspects. This results meet with the observations we have been done along with our study of patients with myotonic dystrophy.

Acknowledgement - The authors are indebted to Rozicler Mendes for her English review.

\section{REFERENCES}

1. Dyken PR, Harper PS. Congenital dystrophia myotonica. Neurology 1973;23:465-473.

2. Duarte CMO, Hora LHM, Duro LAA. Estudos psicológicos na doença de Steinert. V Jornada de Miopatias, Rio de Janeiro RJ: outubro 1985:2.

3. Duarte CMO. Aspectos psicológicos da distrofia miotônica. IX Jornada de Iniciação Científica, UFRJ, Rio de Janeiro RJ: outubro 1986:20.

4. Wigg CMD, Duro LAA. Avaliação psicológica em pacientes com distrofia miotônica. XIV Congresso Brasileiro de Neurologia, Rio de Janeiro RJ: setembro 1990. Arq Neuropsiquiatr 1990;48(Suppl):388.

5. Culebras A, Feldman RG, Merck FB. Cytoplasmic inclusion bodies within neurons of the thalamus in myotonic dystrophy: a light and electron microscope study. J Neurol Sci 1973;19:319-329.

6. Vanier TM. Dystrophia myotonica in childhood. Br Med J 1960;2:1284-1288.

7. Calderon R. Myotonic dystrophy:a neglected cause of mental retardation. J Ped 1966;68:423-431.

8. Zellweger H, Ionasescu V. Early onset of myotonic dystrophy in infants. Am J Dis Childr 1973;125:601-604.

9. Wechsler D. Escala da Inteligência Wechsler para crianças (WISC). Tradução de Ana Maria Poppovic. In Manual de Psicologia Aplicada. Rio de Janeiro: Centro Editor de Psicologia Aplicada, 1977.

10. Lemgruber V, Ann Paine P. Adaptação brasileira da Escala Verbal do WISC. Arq Bras Psicol (Rio de Janeiro) 1981;33:32-56.

11. Mcfie J. Assessment of organic intellectual impairment. London: Academic Press, 1975.

12. Lefevre BH. Neuropsicologia infantil. São Paulo: Sarvier, 1989.

13. Hanafusa H, Motomura N, Asaba H, Sakai T, Kawamura H. Event-related potentials (P 30 ) in myotonic dystrophy. Acta Neurol Scand. 1989;80:111-113.

14. Adams R, Victor M. Neurologic disorders caused by lesions in particular parts of the cerebrum. In Principles of neurology. New York: McGraw-Hill 1993:378-410.

15. Paterson A, Zangwill OL. Disorders of visual space perception associated with lesions of the right cerebral hemisphere. Brain 1944;67:331-358.

16. Lenz H. Rauminnstörungen bei Hinverletzungen. Dtsch Z Nervenh 1944;157:22.

17. McFie J, Piercy MF, Zangwill OL. Visual-spatial associated with lesions of the right cerebral hemisphere. Brain 1950;72:167-190.

18. Marie P, Bouttier M, Bailey P. La planotopokinésie: étude sur les erreurs d'exécution de certains mouvements dans leurs rapports avec la représentation spatiale. Rev Neurol 1922;38:505-517.

19. Censori B, Danini M, Del Pesce M, Provinciali L. Neuropsychological profile in myotonic dystrophy. J Neurol 1990;237:251-256.

20. Granier F. Manifestations psychiatriques de la maladie de Steinert. Ann Med Psychol 1985;144:504-514.

21. Walker GL, Rosser R, Mastaglia FL, Walton JN. Psychometric and cranial CT in myotonic dystrophy. Clin Exp Neurol 1984;20:161-167. 